way to forecast its onset we found is the decrease of the weight curve. Trichomonas and so called Spirochaete type organisms were found occasionally. Prevention with Carbadox 50 p.p.m. during 2 I days treatment during 7 days either with Carbadox 50 p.p.m. or with Dimetridazole 300 p.p.m. were dramatically successful. The total cure was confirmed by a 40 days period of control after the withdrawal of the drugs.

\title{
DONNÉES HÉCENTES CONCERNANT L'IMMUNISATION DU PORCELET
}

\author{
J. - J. METZGER \\ Station de Virologie et d'Immunologie, I. N. R. A., \\ 78 - Thiverval-Grignon \\ RÉSUMÉ
}

L'immunisation des jeunes animaux à l'aide d'antigènes naturels ou artificiels se heurte à de nombreux problèmes tant théoriques que pratiques. Nous avons voulu décrire brièvement les principales raisons des variations souvent observées et tenté de les relier aux phénomènes connus de l'immunologie classique : immunisation en fonction de la nature et de la dose de l'antigène, immunisation passive par les anticorps colostraux, rôle des adjuvants de l'immunité. Les règles d'une immunisation efficace devront donc se déduire à partir de l'analyse de ces facteurs dans le cas précis de l'immunisation souhaitée.

\section{SUMMARY}

\section{RECEN'T DATA ABOU'T PIGLE'T IMMUNIZATION}

Young animal immunization with the aid of natural or artificial antigen displays some variations. A short review of the most important factors involved is given. These factors are mainly related to the antigen nature and dose, to the passive immunity through colostrum and to the adjuvant effects. Rules for better immunization of the piglet can be deduced from the analysis of these factors in the desired case. 